Article

\title{
Saccharobisindole, Neoasterric Methyl Ester, and 7-Chloro-4(1H)-quinolone: Three New Compounds Isolated from the Marine Bacterium Saccharomonospora sp.
}

\author{
Sohee Kim ${ }^{1,+(D)}$, Tu Cam Le ${ }^{2,3,+}$, Sang-Ah Han ${ }^{1,+}{ }^{\text {, Prima F. Hillman }}{ }^{4}$, Ahreum Hong ${ }^{1,5}$, Sunghoon Hwang ${ }^{6}$, \\ Young Eun Du ${ }^{6}$, Hiyoung Kim ${ }^{7}$, Dong-Chan $\mathrm{Oh}^{6}{ }^{6}$, Sun-Shin Cha ${ }^{4}$, Jihye Lee ${ }^{4,5, *}$, Sang-Jip Nam ${ }^{4, *}$
} and William Fenical ${ }^{8, *}$

Citation: Kim, S.; Le, T.C.; Han, S.-A.; Hillman, P.F.; Hong, A.; Hwang, S.;

Du, Y.E.; Kim, H.; Oh, D.-C.;

Cha, S.-S.; et al. Saccharobisindole, Neoasterric Methyl Ester, and 7-Chloro-4(1H)-quinolone: Three New Compounds Isolated from the Marine Bacterium Saccharomonospora sp. Mar. Drugs 2022, 20, 35. https://doi.org/10.3390/ md20010035

Academic Editor: Hee Jae Shin

Received: 6 November 2021

Accepted: 21 December 2021

Published: 29 December 2021

Publisher's Note: MDPI stays neutral with regard to jurisdictional claims in published maps and institutional affiliations.

Copyright: (c) 2021 by the authors. Licensee MDPI, Basel, Switzerland. This article is an open access article distributed under the terms and conditions of the Creative Commons Attribution (CC BY) license (https:// creativecommons.org/licenses/by/ $4.0 /)$.
1 The Graduate School of Industrial Pharmaceutical Sciences, Ewha Womans University, Seoul 03760, Korea; chi0736@naver.com (S.K.); tkddk9559@naver.com (S.-A.H.); lyzenne@naver.com (A.H.)

2 Laboratory of Advanced Materials Chemistry, Advanced Institute of Materials Science, Ton Duc Thang University, Ho Chi Minh City 700000, Vietnam; lecamtu@tdtu.edu.vn

3 Faculty of Applied Sciences, Ton Duc Thang University, Ho Chi Minh City 700000, Vietnam

4 Department of Chemistry and Nanoscience, Ewha Womans University, Seoul 03760, Korea; primafitriah@gmail.com (P.F.H.); cha-jung@ewha.ac.kr (S.-S.C.)

5 Laboratories of Marine New Drugs, REDONE Seoul, Seoul 08594, Korea

6 Natural Products Research Institute, College of Pharmacy, Seoul National University, Seoul 08826, Korea; sunghooi@snu.ac.kr (S.H.); dye0302@snu.ac.kr (Y.E.D.); dongchanoh@snu.ac.kr (D.-C.O.)

7 Department of Biomedical Science and Engineering, Konkuk University, Seoul 05029, Korea; reihyoung@konkuk.ac.kr

8 Center for Marine Biotechnology and Biomedicine, Scripps Institution of Oceanography, University of California-San Diego, La Jolla, CA 92093-0204, USA

* Correspondence: j13414@gmail.com (J.L.); sjnam@ewha.ac.kr (S.-J.N.); wfenical@ucsd.edu (W.F.); Tel.: +82-70-4219-1632 (J.L.); +82-2-3277-6805 (S.-J.N.); +1-858-259-3839 (W.F.)

+ These authors contributed equally to this work.

\begin{abstract}
Analysis of the chemical components from the culture broth of the marine bacterium Saccharomonospora sp. CNQ-490 has yielded three novel compounds: saccharobisindole (1), neoasterric methyl ester (2), and 7-chloro-4(1H)-quinolone (3), in addition to acremonidine $\mathrm{E}$ (4), pinselin (5), penicitrinon A (6), and penicitrinon E (7). The chemical structures of the three novel compounds were elucidated by the interpretation of 1D, 2D nuclear magnetic resonance (NMR), and high-resolution mass spectrometry (HRMS) data. Compound 2 generated weak inhibition activity against Bacillus subtilis KCTC2441 and Staphylococcus aureus KCTC1927 at concentrations of $32 \mu \mathrm{g} / \mathrm{mL}$ and $64 \mu \mathrm{g} / \mathrm{mL}$, respectively, whereas compounds 1 and 3 did not have any observable effects. In addition, compound $\mathbf{2}$ displayed weak anti-quorum sensing (QS) effects against S. aureus KCTC1927 and Micrococcus luteus SCO560.
\end{abstract}

Keywords: Saccharomonospora sp.; marine natural products; antibacterial activity

\section{Introduction}

Actinomycetes, a group of aerobic and anaerobic Gram-positive mycelial bacteria, are known to produce a variety of bioactive secondary metabolites. In fact, more than $70 \%$ of the currently used antibiotics were originally isolated from Streptomyces, the largest genus of actinomycetes [1]. Rare actinomycetes have also been regarded as potential sources for the discovery of bioactive compounds, including antibiotics [1]. In the past five years, $31 \%$ of new bioactive compounds were isolated from rare actinomycete strains, although the Streptomyces genus continues to dominate this field, contributing $65 \%$ of the reported bioactive compounds [2].

The genus Saccharomonospora, a rare actinomycete, was first described in 1971 [3,4] and only a few secondary metabolites have been isolated from this genus [5,6]. The strain CNQ490, Saccharomonospora sp., was isolated from a sediment sample of La Jolla Submarine 
Canyon and previous chemical analyses of strain CNQ-490 led to the identification of seven novel secondary metabolites including lodopyridones A-C $[7,8]$, sacchromonopyrones A-C [9], and saccharoquinoline [10]. Additionally, a genomic study of strain CNQ-490 demonstrated that this bacterium possessed a silent biosynthetic gene cluster, which led to the discovery of the novel antibiotic compounds taromycins A and B [11,12]. The identification of 19 biosynthetic gene clusters in this strain suggested that it could produce a wide structural diversity of secondary metabolites. Further characterization of the bioactive metabolites of strain CNQ-490 led to the discovery of saccharobisindole (1), neoasterric methyl ester (2), and 7-chloro-4 $(1 \mathrm{H})$-quinolone (3), in addition to four known natural products, including acremonidine $\mathrm{E}$ (4), pinselin (5), penicitrinon $\mathrm{A}(6)$, and penicitrinon $\mathrm{E}$ (7) (Figure 1). The present study elucidated the structure of compounds 1-3, as well as the biological activities of $\mathbf{1}-\mathbf{7}$.<smiles>CC(C)=CCc1ccc2c(c1)NC(=O)C2=C1C(=O)Nc2cc(CC=C(C)C)ccc21</smiles>

1<smiles>COC(=O)c1c(O)cc(C)cc1Oc1c(O)ccc(O)c1C(=O)OC</smiles>

2<smiles>COC(=O)c1c(O)ccc2oc3cc(C)cc(O)c3c(=O)c12</smiles>

5<smiles>COC(=O)c1c(O)ccc(O)c1C(=O)c1c(O)cc(C)cc1O</smiles><smiles>[R]c1c2c3c(c(c(C)c1=O)[C@H](C)[C@@H](C)O3)-c1c(O)c(C)c3c(c1O2)O[C@@H](C)[C@@H]3C</smiles>

$6 \mathrm{R}=\mathrm{H}$

$7 \mathrm{R}=\mathrm{COOH}$

Figure 1. Chemical structures of saccharobisindole (1), neoasterric methyl ester (2), 7-chloro-4(1H)quinolone (3), acremonidine E (4), pinselin (5), penicitrinon A (6), and penicitrinon E (7).

\section{Results}

Saccharobisindole (1) was obtained as a pale, yellow oil. The molecular formula of this compound $\left(\mathrm{C}_{26} \mathrm{H}_{28} \mathrm{~N}_{2} \mathrm{O}_{3}\right)$ was deduced from high-resolution fast atom bombardment mass spectrometry (HRFABMS) coupled with the detection of an ion at $m / z 417.2181[\mathrm{M}+\mathrm{H}]^{+}$ (calcd for $\mathrm{C}_{26} \mathrm{H}_{29} \mathrm{~N}_{2} \mathrm{O}_{3}, 417.2178$ ) indicating 14 degrees of unsaturation. The infrared (IR) spectrum of this compound indicated the presence of a hydroxy group at $3431 \mathrm{~cm}^{-1}$, a carbonyl group at $1676 \mathrm{~cm}^{-1}$, and a double bond at $1638 \mathrm{~cm}^{-1}$.

The ${ }^{1} \mathrm{H}$ NMR spectrum of 1 exhibited two sets of 1,2,4-trisubstituted aromatic protons H-6 $\left(\delta_{\mathrm{H}} 6.55,1 \mathrm{H}, \mathrm{s}\right), \mathrm{H}-8\left(\delta_{\mathrm{H}} 6.80,1 \mathrm{H}, \mathrm{d}, J=7.7 \mathrm{~Hz}\right), \mathrm{H}-9\left(\delta_{\mathrm{H}} 7.35,1 \mathrm{H}, \mathrm{d}, J=7.7 \mathrm{~Hz}\right), \mathrm{H}-6^{\prime}$ $\left(\delta_{\mathrm{H}} 6.53,1 \mathrm{H}, \mathrm{s}\right), \mathrm{H}-8^{\prime}\left(\delta_{\mathrm{H}} 6.45,1 \mathrm{H}, \mathrm{d}, J=7.6 \mathrm{~Hz}\right)$, and $\mathrm{H}-9^{\prime}\left(\delta_{\mathrm{H}} 6.09,1 \mathrm{H}, \mathrm{d}, J=7.6 \mathrm{~Hz}\right)$, four methyl singlets $\mathrm{H}-13\left(\delta_{\mathrm{H}} 1.72,3 \mathrm{H}, \mathrm{s}\right), \mathrm{H}-14\left(\delta_{\mathrm{H}} 1.69,3 \mathrm{H}, \mathrm{s}\right), \mathrm{H}-13^{\prime}\left(\delta_{\mathrm{H}} 1.68,3 \mathrm{H}, \mathrm{s}\right)$, and H-14 ${ }^{\prime}$ $\left(\delta_{\mathrm{H}} 1.64,3 \mathrm{H}, \mathrm{s}\right)$, two triplet olefinic proton signals $\mathrm{H}-11\left(\delta_{\mathrm{H}} 5.29,1 \mathrm{H}, \mathrm{t}, J=7.3 \mathrm{~Hz}\right)$ and $\mathrm{H}-11^{\prime}\left(\delta_{\mathrm{H}} 5.21,1 \mathrm{H}, \mathrm{t}, J=7.5 \mathrm{~Hz}\right)$, two doublet protons $\mathrm{H}-10\left(\delta_{\mathrm{H}} 3.30,2 \mathrm{H}, \mathrm{d}, J=7.9 \mathrm{~Hz}\right)$ and $\mathrm{H}-10^{\prime}\left(\delta_{\mathrm{H}} 3.19,2 \mathrm{H}, \mathrm{d}, J=7.5 \mathrm{~Hz}\right)$, and one singlet proton $\mathrm{H}-3\left(\delta_{\mathrm{H}} 3.91,1 \mathrm{H}, \mathrm{s}\right)$. Furthermore, three exchangeable protons at NH-1 $\left(\delta_{\mathrm{H}} 10.08\right), \mathrm{NH}-1^{\prime}\left(\delta_{\mathrm{H}} 10.22\right)$, and $3^{\prime}-\mathrm{OH}\left(\delta_{\mathrm{H}} 6.40\right)$ were also observed in the ${ }^{1} \mathrm{H}$ NMR spectrum. The analysis of ${ }^{13} \mathrm{C}$ NMR and heteronuclear single quantum coherence (HSQC) spectroscopic data indicated two carbonyl C-2 $\left(\delta_{\mathrm{C}} 174.6\right)$ and $\mathrm{C}-2^{\prime}\left(\delta_{\mathrm{C}} 177.3\right)$, eight sp ${ }^{2}$ quaternary C-4 $\left(\delta_{\mathrm{C}} 123.2\right), \mathrm{C}-5\left(\delta_{\mathrm{C}} 143.4\right), \mathrm{C}-7\left(\delta_{\mathrm{C}} 141.8\right), \mathrm{C}-12$ $\left(\delta_{\mathrm{C}} 131.8\right), \mathrm{C}-4^{\prime}\left(\delta_{\mathrm{C}} 125.8\right), \mathrm{C}-5^{\prime}\left(\delta_{\mathrm{C}} 142.9\right), \mathrm{C}-7^{\prime}\left(\delta_{\mathrm{C}} 143.1\right)$, and $\mathrm{C}-12^{\prime}\left(\delta_{\mathrm{C}} 131.9\right)$, six aromatic methine C-6 $\left(\delta_{\mathrm{C}} 108.8\right), \mathrm{C}-8\left(\delta_{\mathrm{C}} 120.9\right), \mathrm{C}-9\left(\delta_{\mathrm{C}} 126.2\right), \mathrm{C}-6^{\prime}\left(\delta_{\mathrm{C}} 109.4\right), \mathrm{C}-8^{\prime}\left(\delta_{\mathrm{C}} 120.8\right)$, and $C-9^{\prime}\left(\delta_{\mathrm{C}} 123.5\right)$, two olefinic C-11 $\left(\delta_{\mathrm{C}} 123.2\right)$ and $\mathrm{C}-11^{\prime}\left(\delta_{\mathrm{C}} 122.9\right)$, two methylene C-10 $\left(\delta_{\mathrm{C}} 33.8\right)$ and $\mathrm{C}-10^{\prime}\left(\delta_{\mathrm{C}} 33.7\right)$, and four methyl singlet carbons $\mathrm{C}-13\left(\delta_{\mathrm{C}} 25.5\right), \mathrm{C}-14\left(\delta_{\mathrm{C}} 17.7\right)$, $\mathrm{C}-13^{\prime}\left(\delta_{\mathrm{C}} 25.4\right)$, and $\mathrm{C}-14^{\prime}\left(\delta_{\mathrm{C}} 17.6\right)$, along with one sp ${ }^{3}$ methine group $\mathrm{C}-3\left(\delta_{\mathrm{C}} 51.1\right)$ and one $\mathrm{sp}^{3}$ quaternary carbon $\mathrm{C}-3^{\prime}\left(\delta_{\mathrm{C}} 75.4\right)$ (Table 1$)$. 
Table 1. NMR spectroscopic data for saccharobisindole (1) and neoasterric methyl ester (2) in DMSO- $d_{6}{ }^{1}$, and 7-chloro-4(1H)-quinolone (3) in $\mathrm{CD}_{3} \mathrm{OD}{ }^{2}$.

\begin{tabular}{|c|c|c|c|c|c|c|c|c|c|c|c|c|}
\hline \multirow{2}{*}{ No. } & \multicolumn{5}{|c|}{ Saccharobisindole (1) } & \multicolumn{4}{|c|}{ Neoasterric Methyl Ester (2) } & \multicolumn{3}{|c|}{ 7-Chloro-4(1H)-quinolone (3) } \\
\hline & $\delta \mathrm{C}$, Type $^{3}$ & $\delta \mathbf{H},(J$ in $\mathbf{H z})$ & COSY & НМВС & $\delta \mathrm{C}$, Type $^{3}$ & $\delta \mathbf{H},(J$ in $\mathbf{H z})$ & COSY & НМВС & $\delta \mathrm{C}$, Type $^{3}$ & $\delta \mathbf{H},(J$ in $\mathbf{H z})$ & COSY & НМВС \\
\hline 1 & $\mathrm{NH}$ & $10.08, \mathrm{~s}$ & & $\mathrm{C}-2,3,4,5$ & $156.3, \mathrm{C}$ & & & & & & & \\
\hline 2 & $174.6, \mathrm{C}$ & & & & $105.1, \mathrm{CH}$ & $5.77, \mathrm{~s}$ & & C- $-1,4,6$ & $142.2, \mathrm{CH}$ & $8.01, \mathrm{~d}(7.3)$ & $\mathrm{H}-3$ & $C-3,4,8 \mathrm{a}$ \\
\hline 4 & $123.2, \mathrm{C}$ & & & & $109.7 \mathrm{CH}$ & $6.32, \mathrm{~s}$ & & $C-1,2,6,7$ & $179.8, \mathrm{C}$ & & & \\
\hline $4 a$ & & & & & & & & & $125.1, \mathrm{C}$ & & & \\
\hline 5 & $143.4, \mathrm{C}$ & & & & 156.0, C & & & & $128.3, \mathrm{CH}$ & 8.24, d (8.8) & H-6 & $\mathrm{C}-4,7,8,8 \mathrm{a}$ \\
\hline 6 & $108.8, \mathrm{CH}$ & $6.55, \mathrm{~s}$ & $\mathrm{H}-8$ & C- $-4,8,10$ & 107.2, C & & & & $126.1, \mathrm{CH}$ & 7.42, dd $(8.8,1.9)$ & $\mathrm{H}-5$ & $\mathrm{C}-4 \mathrm{a}, 8,8 \mathrm{a}$ \\
\hline 8 & $120.9, \mathrm{CH}$ & $6.80, \mathrm{~d}(7.7)$ & $\mathrm{H}-6,9$ & $C-4,6,10$ & $51.8, \mathrm{CH} 3$ & $3.75, \mathrm{~s}$ & & $\mathrm{C}-7$ & $118.9, \mathrm{CH}$ & $7.63, \mathrm{~d}(1.9)$ & & $C-4 a, 6,8 a$ \\
\hline $8 a$ & & & & & & & & & $139.8, \mathrm{C}$ & & & \\
\hline 9 & $126.2, \mathrm{CH}$ & $7.35, \mathrm{~d}(7.7)$ & $\mathrm{H}-8$ & C- $-5,7$ & $21.4, \mathrm{CH} 3$ & $2.08, \mathrm{~s}$ & 2,4 & $C-2,3,4$ & & & & \\
\hline 10 & $33.8, \mathrm{CH} 2$ & 3.30, d (7.9) & $\mathrm{H}-11$ & $C-6,7,8,11,12$ & & & & & & & & \\
\hline 11 & $123.2, \mathrm{CH}$ & $5.29, \mathrm{t}(7.9)$ & $\mathrm{H}-10$ & C- $10,13,14$ & & & & & & & & \\
\hline 12 & $131.8, \mathrm{C}$ & & & & & & & & & & & \\
\hline 13 & $25.5, \mathrm{CH} 3$ & $1.72, \mathrm{~s}$ & & C- $-11,12,14$ & & & & & & & & \\
\hline 14 & $17.7, \mathrm{CH} 3$ & $1.69, \mathrm{~s}$ & & $\mathrm{C}-11,12,13$ & & & & & & & & \\
\hline $1^{\prime}$ & $\mathrm{NH}$ & $10.22, \mathrm{~s}$ & & $C-3^{\prime}, 4^{\prime}, 5^{\prime}$ & $142.2, \mathrm{C}$ & & & & & & & \\
\hline $3^{\prime}$ & $75.4, \mathrm{C}$ & & & & $118.9, \mathrm{CH}$ & 6.87, d (8.7) & $2^{\prime}$ & $C-1^{\prime}, 4^{\prime}, 5^{\prime}$ & & & & \\
\hline $4^{\prime}$ & $125.8, \mathrm{C}$ & & & & 138.0, C & & & & & & & \\
\hline $5^{\prime}$ & $142.9, \mathrm{C}$ & & & & 147.7, C & & & & & & & \\
\hline $6^{\prime}$ & 109.4, $\mathrm{CH}$ & $6.53, \mathrm{~s}$ & $\mathrm{H}-8^{\prime}$ & $C-4^{\prime}, 8^{\prime}, 10^{\prime}$ & $116.6, \mathrm{C}$ & & & & & & & \\
\hline $7^{\prime}$ & 143.1, C & & & & $165.5, \mathrm{C}$ & & & & & & & \\
\hline $8^{\prime}$ & $120.8, \mathrm{CH}$ & $6.45, \mathrm{~d}(7.6)$ & H-9' & $C-4^{\prime}, 6^{\prime}, 10^{\prime}$ & $51.8, \mathrm{CH} 3$ & $3.61, \mathrm{~s}$ & & $C-7^{\prime}$ & & & & \\
\hline $9^{\prime}$ & $123.5, \mathrm{CH}$ & $6.09, \mathrm{~d}(7.6)$ & $\mathrm{H}-6^{\prime}, 8^{\prime}$ & $\mathrm{C}-5^{\prime}, 7^{\prime}$ & & & & & & & & \\
\hline $10^{\prime}$ & $33.7, \mathrm{CH} 2$ & $3.19, \mathrm{~d}(7.5)$ & $\mathrm{H}-11^{\prime}$ & $C-6^{\prime}, 7^{\prime}, 8^{\prime}, 11^{\prime}, 12^{\prime}$ & & & & & & & & \\
\hline $11^{\prime}$ & $122.9, \mathrm{CH}$ & $5.21, \mathrm{t}(7.5)$ & $\mathrm{H}-10^{\prime}$ & C- $10^{\prime}, 13^{\prime}, 14^{\prime}$ & & & & & & & & \\
\hline $12^{\prime}$ & $131.9, \mathrm{C}$ & & & & & & & & & & & \\
\hline $13^{\prime}$ & $25.4, \mathrm{CH} 3$ & $1.68, \mathrm{~s}$ & & $\mathrm{C}-11^{\prime}, 12^{\prime}, 14^{\prime}$ & & & & & & & & \\
\hline $14^{\prime}$ & $17.6, \mathrm{CH} 3$ & $1.64, \mathrm{~s}$ & & $\mathrm{C}-11^{\prime}, 12^{\prime}, 13^{\prime}$ & & & & & & & & \\
\hline $5-\mathrm{OH}$ & & & & & $10.06, \mathrm{~s}$ & & & $C-4,5,6$ & & & & \\
\hline $1^{\prime}-\mathrm{OH}$ & & & & & $9.56, \mathrm{~s}$ & & & $C-1^{\prime}, 2^{\prime}, 6^{\prime}$ & & & & \\
\hline $3^{\prime}-\mathrm{OH}$ & & $6.40, \mathrm{~s}$ & & $C-3,3^{\prime}, 4^{\prime}$ & & & & & & & & \\
\hline $4^{\prime}-\mathrm{OH}$ & & & & & $9.70, \mathrm{~s}$ & & & $C-3^{\prime}, 4^{\prime}, 5^{\prime}$ & & & & \\
\hline
\end{tabular}

${ }^{1} 300 \mathrm{MHz}$ for ${ }^{1} \mathrm{H}$ NMR and $75 \mathrm{MHz}$ for ${ }^{13} \mathrm{C}$ NMR.; ${ }^{2} 400 \mathrm{MHz}$ for ${ }^{1} \mathrm{H}$ NMR and $100 \mathrm{MHz}$ for ${ }^{13} \mathrm{C}$ NMR.; ${ }^{3}$ Multiplicity was determined by the analysis of $2 \mathrm{D}$ NMR spectroscopic data. 
Further interpretation of 2D NMR spectroscopic data including two-bond HMBC (heteronuclear multiple bond correlation) analysis allowed for the structural construction of 1. Two sets of indolin-2-one moieties were identified by the interpretation of COSY (COrrelated SpectroscopY) and HMBC spectral data. The COSY cross peaks $\mathrm{H}-6 / \mathrm{H}-8 / \mathrm{H}-9$ and $\mathrm{H}-6^{\prime} / \mathrm{H}-8^{\prime} / \mathrm{H}-9^{\prime}$ and the long-range HMBC correlations $\mathrm{H}-8\left(\delta_{\mathrm{H}} 6.80\right) / \mathrm{C}-4\left(\delta_{\mathrm{C}} 123.2\right)$, C-6 $\left(\delta_{\mathrm{C}} 108.8\right) ; \mathrm{H}-9\left(\delta_{\mathrm{H}} 7.35\right) / \mathrm{C}-5\left(\delta_{\mathrm{C}} 143.4\right), \mathrm{C}-7\left(\delta_{\mathrm{C}} 141.8\right)$; singlet aromatic proton H-6 $\left(\delta_{\mathrm{H}} 6.55\right) / \mathrm{C}-4, \mathrm{C}-8\left(\delta_{\mathrm{C}} 120.9\right) ; \mathrm{H}-8^{\prime}\left(\delta_{\mathrm{H}} 6.45\right) / \mathrm{C}-4^{\prime}\left(\delta_{\mathrm{C}} 125.8\right), \mathrm{C}-6^{\prime}\left(\delta_{\mathrm{C}} 109.4\right) ; \mathrm{H}-9^{\prime}\left(\delta_{\mathrm{H}} 6.09\right) /$ $\mathrm{C}-5^{\prime}\left(\delta_{\mathrm{C}} 142.9\right), \mathrm{C}-7^{\prime}\left(\delta_{\mathrm{C}} 143.1\right)$; and $\mathrm{H}-6^{\prime}\left(\delta_{\mathrm{H}} 6.53\right) / \mathrm{C}-4^{\prime}, \mathrm{C}-8^{\prime}\left(\delta_{\mathrm{C}} 120.8\right)$ confirmed the presence of two sets of 1,2,4-trisubstituted benzene moieties. Furthermore, two sets of 3-methylbut-2-enyl moieties were also identified from the interpretation of COSY and log-range HMBC analyses. COSY crosspeaks $\mathrm{H}-10 / \mathrm{H}-11$ and $\mathrm{H}-10^{\prime} / \mathrm{H}-11^{\prime}$ and long-range $\mathrm{HMBC}$ correlations $\mathrm{H}-13\left(\delta_{\mathrm{H}} 1.72\right)$ and $\mathrm{H}-14\left(\delta_{\mathrm{H}} 1.69\right) / \mathrm{C}-11\left(\delta_{\mathrm{C}} 123.2\right), \mathrm{C}-12\left(\delta_{\mathrm{C}} 131.8\right)$; $\mathrm{H}-10\left(\delta_{\mathrm{H}} 3.30\right) / \mathrm{C}-11\left(\delta_{\mathrm{C}} 123.2\right), \mathrm{C}-12\left(\delta_{\mathrm{C}} 131.8\right) ; \mathrm{H}-13^{\prime}\left(\delta_{\mathrm{H}} 1.68\right)$ and H-14 ${ }^{\prime}\left(\delta_{\mathrm{H}} 1.64\right) / \mathrm{C}-11^{\prime}$ $\left(\delta_{\mathrm{C}} 122.9\right), \mathrm{C}-12^{\prime}\left(\delta_{\mathrm{C}} 131.9\right) ;$ and $\mathrm{H}-10^{\prime}\left(\delta_{\mathrm{H}} 3.19\right) / \mathrm{C}-11^{\prime}\left(\delta_{\mathrm{C}} 122.9\right), \mathrm{C}-12^{\prime}\left(\delta_{\mathrm{C}} 131.9\right)$ allowed for the assignment of two sets of 3-methylbut-2-enyl units.

One set of indolin-2-one moieties with a 3-methylbut-2-enyl group was identified via analysis of HMBC correlations (Figure 2). HMBC correlations from $\mathrm{H}-10$ to $\mathrm{C}-7\left(\delta_{\mathrm{C}} 141.8\right)$, and from H-6 $\left(\delta_{\mathrm{H}} 6.55\right)$ and $\mathrm{H}-8\left(\delta_{\mathrm{H}} 6.80\right)$ to $\mathrm{C}-10\left(\delta_{\mathrm{C}} 33.8\right)$ allowed for the attachment of a 3-methylbut-2-enyl group at C-7 of the benzene ring system. Further, HMBC correlations from the exchangeable NH-1 proton $\left(\delta_{\mathrm{H}} 10.08\right)$ to $\mathrm{C}-5\left(\delta_{\mathrm{C}} 143.4\right)$ and the carbonyl carbon $\mathrm{C}-2\left(\delta_{\mathrm{C}} 174.6\right)$, and from the methine proton $\mathrm{H}-3\left(\delta_{\mathrm{H}} 3.91\right)$ to $\mathrm{C}-2, \mathrm{C}-4\left(\delta_{\mathrm{C}} 123.2\right)$, and $\mathrm{C}-5$, allowed for the assignment of an indolin-2-one moiety with a 3-methylbut-2-enyl group. Similarly, the other indolin-2-one moiety with a 3-methylbut-2-enyl group was also assigned by interpretation of HMBC correlations. Briefly, HMBC correlations of H-10' $\left(\delta_{\mathrm{H}} 3.19\right) / \mathrm{C}-7^{\prime}\left(\delta_{\mathrm{C}} 143.1\right) ; \mathrm{H}-6^{\prime}\left(\delta_{\mathrm{H}} 6.53\right)$ and $\mathrm{H}-8^{\prime}\left(\delta_{\mathrm{H}} 6.45\right) / \mathrm{C}-10^{\prime}\left(\delta_{\mathrm{C}} 33.7\right)$; and NH-1' $/$ $\mathrm{C}-3^{\prime}\left(\delta_{\mathrm{C}} 75.4\right), \mathrm{C}-4^{\prime}\left(\delta_{\mathrm{C}} 125.8\right), \mathrm{C}-5^{\prime}\left(\delta_{\mathrm{C}} 142.9\right)$ provided further evidence for the assignment of an indolin-2-one moiety with a 3-methylbut-2-enyl group. A hydroxy group at $\delta_{\mathrm{H}} 6.40$ was attached to $\mathrm{C}-3^{\prime}$ based on HMBC correlations from this exchangeable proton to C- $3^{\prime}$ and $C-4^{\prime}$, as well as the consideration of the carbon chemical shift of $C-3^{\prime}\left(\delta_{C} 75.4\right)$. Lastly, the connection between C-3 and C- $3^{\prime}$ of two indolin-2-one moieties was secured from the observation of HMBC correlations from $\mathrm{H}-3$ to $\mathrm{C}-3^{\prime}$, thus completing the assignment of 1 (Figure 1). The relative configurations of $\mathbf{1}$ were deduced from the interpretation of nuclear Overhauser effect spectroscopy (NOESY) data. The NOESY correlation of $\mathbf{1}$ between H-3 and the 3 '-OH protons indicated that the proton and hydroxy group should be placed at the same side of the rings (Figure 2). The absolute configuration of 1 was determined by calculating the experimental ECD data of $\mathbf{1}$ using density functional theory (DFT) modeling. The possible enantiomers of compound 1 were selected based on NOESY NMR data. The observed ECD spectrum of compound 1 showed a positive Cotton Effect around $291 \mathrm{~nm}$. Comparison of the calculated ECD data of the two enantiomers with that measured, allowed the absolute configurations of compound 1 to be assigned as $R, S$ (Figure 3). This result was also supported by comparing the experimental and calculated values of optical rotations. Compound 1 had a positive optical rotation value $[\alpha]_{D}^{25}=+161$ ). The calculated values of optical rotations for four theoretical stereoisomers indicated that three stereoisomers had all negative values and only the stereoisomer with $1 \mathrm{R}, 1^{\prime} \mathrm{S}$ configurations displayed a positive value $\left([\alpha]_{D}^{25}=+40\right)$. Therefore, 1 was assigned as $1 R, 1^{\prime} S$ configuration (Figure S8). Compound $\mathbf{1}$ is an isatin derivative with structural differences at the side chains on two sets of indole moieties. Isatin itself was isolated from the plant Cephalanceropsis gracilis [13] and the deep-sea bacterium Shewanella piezotolerans [14]. 


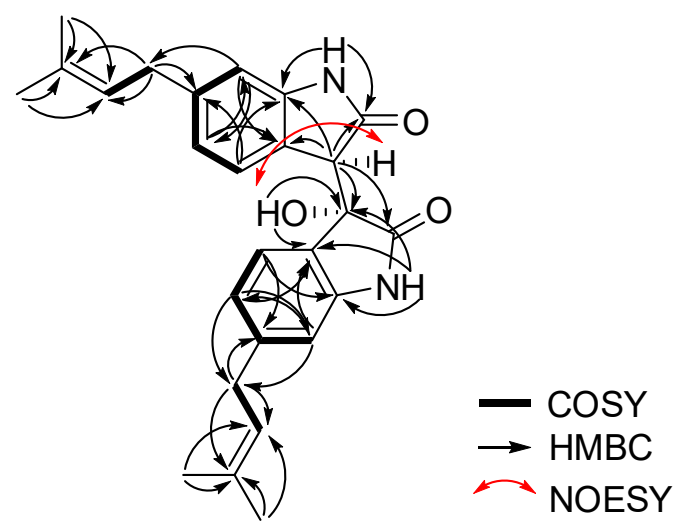

Figure 2. COSY, key HMBC and key NOESY correlations of saccharobisindole (1).

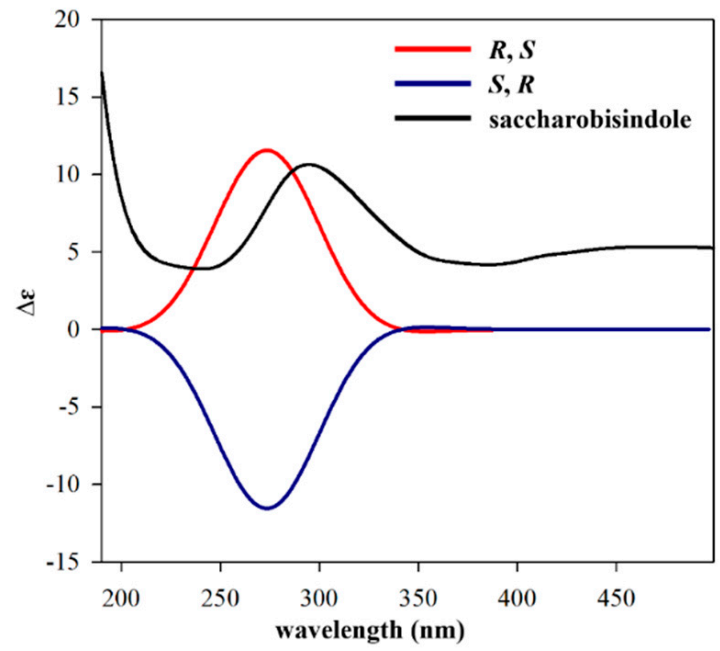

Figure 3. ECD spectra of saccharobisindole (1) and other isomers.

Neoasterric methyl ester (2) was isolated as a yellowish oil and its molecular formula was assigned as $\mathrm{C}_{17} \mathrm{H}_{16} \mathrm{O}_{8}$ as determined by high-resolution fast atom bombardment mass spectrometry which illustrated a $[\mathrm{M}+\mathrm{H}]^{+} \mathrm{m} / \mathrm{z}$ value of 348.0849 (calcd for $\mathrm{C}_{17} \mathrm{H}_{16} \mathrm{O}_{8}$, 348.0845), (HRFABMS). The IR absorptions at $3320 \mathrm{~cm}^{-1}$ and $1660 \mathrm{~cm}^{-1}$ indicated hydroxy and carbonyl functionalities, respectively. The ${ }^{1} \mathrm{H}$ NMR spectrum showed bands for a 1,2,3,5-tetrasubstituted phenyl unit with two protons at $\mathrm{H}-2\left(\delta_{\mathrm{H}} 5.77,1 \mathrm{H}, \mathrm{s}\right)$ and $\mathrm{H}-4\left(\delta_{\mathrm{H}} 6.32\right.$, $1 \mathrm{H}, \mathrm{s})$, a 1,2,3,4-tetrasubstituted phenyl group at $\mathrm{H}-2^{\prime}\left(\delta_{\mathrm{H}} 6.64,1 \mathrm{H}, \mathrm{d}, J=8.7 \mathrm{~Hz}\right)$ and $\mathrm{H}-3^{\prime}$ $\left(\delta_{\mathrm{H}} 6.87,1 \mathrm{H}, \mathrm{d}, J=8.7 \mathrm{~Hz}\right)$, two methoxy groups $\mathrm{H}-8\left(\delta_{\mathrm{H}} 3.75,3 \mathrm{H}, \mathrm{s}\right)$ and $\mathrm{H}-8^{\prime}\left(\delta_{\mathrm{H}} 3.61\right.$, $3 \mathrm{H}, \mathrm{s})$, and one methyl singlet $\mathrm{H}-9\left(\delta_{\mathrm{H}} 2.08,3 \mathrm{H}, \mathrm{s}\right)$. The ${ }^{1} \mathrm{H},{ }^{13} \mathrm{C}$ and HSQC spectroscopic data revealed one methyl C-9 $\left(\delta_{\mathrm{C}} 21.4\right)$, two methoxys C-8 $\left(\delta_{\mathrm{C}} 51.8\right)$ and $\mathrm{C}-8^{\prime}\left(\delta_{\mathrm{C}} 51.8\right)$, two carbonyls $\mathrm{C}-7\left(\delta_{\mathrm{C}} 166.9\right)$ and C-7 $\left(\delta_{\mathrm{C}} 165.5\right)$, four aromatic methines $\mathrm{C}-2\left(\delta_{\mathrm{C}} 105.1\right), \mathrm{C}-4$ $\left(\delta_{\mathrm{C}} 109.7\right), \mathrm{C}-2^{\prime}\left(\delta_{\mathrm{C}} 113.3\right)$, and $\mathrm{C}-3^{\prime}\left(\delta_{\mathrm{C}} 118.9\right)$, and eight quaternary carbons $\mathrm{C}-1\left(\delta_{\mathrm{C}} 156.3\right)$, $\mathrm{C}-3\left(\delta_{\mathrm{C}} 141.1\right), \mathrm{C}-5\left(\delta_{\mathrm{C}} 156.0\right), \mathrm{C}-6\left(\delta_{\mathrm{C}} 107.2\right), \mathrm{C}-1^{\prime}\left(\delta_{\mathrm{C}} 142.2\right), \mathrm{C}-4^{\prime}\left(\delta_{\mathrm{C}} 138.0\right), \mathrm{C}-5^{\prime}\left(\delta_{\mathrm{C}} 147.7\right)$, and $\mathrm{C}-6^{\prime}\left(\delta_{\mathrm{C}} 116.6\right)$ (Table 1$)$.

Analysis of COSY and HMBC spectroscopic data allowed the chemical structure of 2 to be assigned (Figure 4$)$. HMBC correlations from H-2 $\left(\delta_{\mathrm{H}} 5.77\right)$ to $\mathrm{C}-1\left(\delta_{\mathrm{C}} 156.3\right), \mathrm{C}-4$ $\left(\delta_{\mathrm{C}} 109.7\right)$, and C-6 $\left(\delta_{\mathrm{C}} 107.2\right)$ and from $\mathrm{H}-4\left(\delta_{\mathrm{H}} 6.32\right)$ to $\mathrm{C}-1$ and $\mathrm{C}-2\left(\delta_{\mathrm{C}} 105.1\right)$ supported the presence of a 1,2,3,5 substituted benzene moiety. Furthermore, the observation of HMBC correlations from the exchangeable proton $5-\mathrm{OH}\left(\delta_{\mathrm{H}} 10.06\right)$ to $\mathrm{C}-4, \mathrm{C}-5\left(\delta_{\mathrm{C}} 156.0\right)$, and C-6 permitted the $\mathrm{C}-5 / 5-\mathrm{OH}$ connectivity. $\mathrm{HMBC}$ correlations from the methyl singlet protons $\mathrm{H}-9\left(\delta_{\mathrm{H}} 2.08\right)$ to $\mathrm{C}-2, \mathrm{C}-3\left(\delta_{\mathrm{C}} 141.1\right)$ and $\mathrm{C}-4$ indicated that a methyl group was positioned at $\mathrm{C}-3$. A methoxy group was then assigned as part of a methyl ester located at C-7 $\left(\delta_{\mathrm{C}} 166.9\right)$ according to analysis of the three-bond HMBC correlation from $\mathrm{H}-8\left(\delta_{\mathrm{H}} 3.75\right)$ to C-7. The 
long-range HMBC correlation from H-4 to C-6 $\left(\delta_{\mathrm{C}} 107.2\right)$ and C-7 $\left(\delta_{\mathrm{C}} 166.9\right)$ with the typical carbon chemical shift of C-6 $\left(\delta_{\mathrm{C}}\right.$ 107.2) suggested the attachment of C-6 to C-7. The orthocoupled protons $\left(\mathrm{H}-2^{\prime}\right.$ and $\left.\mathrm{H}-3^{\prime}, J=8.7 \mathrm{~Hz}\right)$ displayed the COSY cross peaks $\mathrm{H}-2^{\prime} / \mathrm{H}-3^{\prime}$ and the HMBC correlations with C-1' $1^{\prime}\left(\delta_{\mathrm{C}} 142.2\right), \mathrm{C}-5^{\prime}\left(\delta_{\mathrm{C}} 147.7\right)$, and C-6 $6^{\prime}\left(\delta_{\mathrm{C}} 116.0\right)$ and C-1', $\mathrm{C}-4^{\prime}\left(\delta_{\mathrm{C}} 138.1\right)$, and $\mathrm{C}-5^{\prime}$, respectively. Based on these correlations, a 1,2,3,4 substituted aromatic moiety was established. The two exchangeable protons of $1^{\prime}-\mathrm{OH}\left(\delta_{\mathrm{H}} 9.56\right)$ and $4^{\prime}-\mathrm{OH}\left(\delta_{\mathrm{H}} 9.70\right)$ were placed at $\mathrm{C}-1^{\prime}$ and $\mathrm{C}-4^{\prime}$, respectively, based on the observation of $\mathrm{HMBC}$ correlations from $1^{\prime}-\mathrm{OH}$ to $\mathrm{C}-1^{\prime}, \mathrm{C}-2^{\prime}\left(\delta_{\mathrm{C}} 113.3\right)$, and $\mathrm{C}-6^{\prime}$ and from the $4^{\prime}-\mathrm{OH}$ to $\mathrm{C}-3^{\prime}\left(\delta_{\mathrm{C}} 118.9\right), \mathrm{C}-4^{\prime}$, and $\mathrm{C}-5^{\prime}$. The HMBC correlation from the methoxy protons $\mathrm{H}-8^{\prime}$ to $\mathrm{C}-7^{\prime}\left(\delta_{\mathrm{C}} 165.5\right)$ suggested the presence of a methyl ester moiety and this functional group was placed at C- $6^{\prime}\left(\delta_{\mathrm{C}} 116.6\right)$ based on the identification of a long-range HMBC correlation from $\mathrm{H}-2^{\prime}\left(\delta_{\mathrm{H}} 6.64\right)$ to C-6'. Lastly, the linkage of two aromatic rings through an oxygen atom (C-5' /O/C-1) was deduced from the typical oxygenated carbon chemical shifts of C-1 $\left(\delta_{\mathrm{C}} 156.3\right)$ and $\mathrm{C}-5^{\prime}\left(\delta_{\mathrm{C}}\right.$ 147.7). Compound 2 is an analog of asterric acid. Methyl asterrate, an asterric acid derivative, is most structurally similar to 2 except for the hydroxy group at $\mathrm{C}-4^{\prime}$ and the ortho-coupled protons $\left(\mathrm{H}-2^{\prime}\right.$ and $\left.\mathrm{H}-3^{\prime}, J=8.7 \mathrm{~Hz}\right)$ [15]. Methyl asterrate, also reported as trimethyllosoic acid, was isolated from fungi strains such as Aspergillus sp. [15], Oospora sp. [16], Dothideomycete sp. [17], Phoma sp. [18], Pleosporales sp. [19], Preussia sp. [20], and Geomyces sp. [21]. Methyl asterrate was found to display low cytotoxic activity in the HepG2 cell line with $22 \%$ growth inhibition at a $100 \mu \mathrm{g} / \mathrm{mL}$ concentration [17].

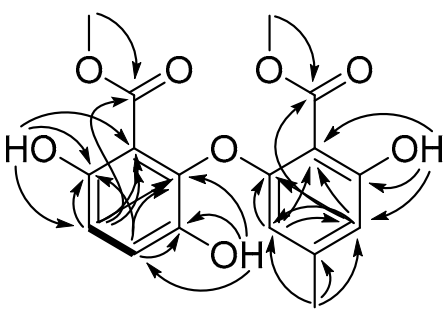

2

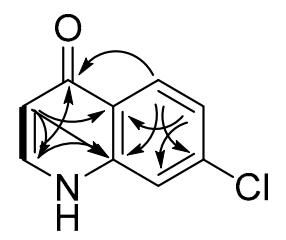

3

Figure 4. COSY and key HMBC correlations of neoasterric methyl ester (2) and 7-chloro-4(1H)quinolone (3).

7-Chloro-4(1H)-quinolone (3) was isolated as a white amorphous powder and its chemical formula was assigned as $\mathrm{C}_{9} \mathrm{H}_{6}{ }^{35} \mathrm{ClNO}$ based on the observation of a protonated molecular ion peak at $m / z 180.0218[\mathrm{M}+\mathrm{H}]^{+}$(calcd for $\mathrm{C}_{9} \mathrm{H}_{6}{ }^{35} \mathrm{ClNO}, 180.0216$ ) in the HRFAB mass spectrum. The ${ }^{1} \mathrm{H}$ NMR spectrum of 3 displayed two deshielded olefinic protons $\mathrm{H}-2$ $\left(\delta_{\mathrm{H}} 8.01,1 \mathrm{H}, \mathrm{d}, J=7.3 \mathrm{~Hz}\right)$ and $\mathrm{H}-3\left(\delta_{\mathrm{H}} 6.37,1 \mathrm{H}, \mathrm{d}, J=7.3 \mathrm{~Hz}\right)$, and a 1,3,4-trisubstituted benzene ring with protons at $\mathrm{H}-5\left(\delta_{\mathrm{H}} 8.24,1 \mathrm{H}, \mathrm{d}, J=8.8 \mathrm{~Hz}\right)$ and $\mathrm{H}-6\left(\delta_{\mathrm{H}} 7.42,1 \mathrm{H}\right.$, dd, $J=8.8,1.9 \mathrm{~Hz})$, and $\mathrm{H}-8\left(\delta_{\mathrm{H}} 7.63,1 \mathrm{H}, \mathrm{d}, J=1.9 \mathrm{~Hz}\right)$. The ${ }^{13} \mathrm{C}$ NMR spectrum exhibited nine carbons C-2 $\left(\delta_{\mathrm{C}} 142.2\right), \mathrm{C}-3\left(\delta_{\mathrm{C}} 110.3\right), \mathrm{C}-4\left(\delta_{\mathrm{C}} 179.8\right), \mathrm{C}-4 \mathrm{a}\left(\delta_{\mathrm{C}} 125.1\right), \mathrm{C}-5\left(\delta_{\mathrm{C}} 128.3\right), \mathrm{C}-6$ $\left(\delta_{\mathrm{C}} 126.1\right), \mathrm{C}-7\left(\delta_{\mathrm{C}} 142.2\right), \mathrm{C}-8\left(\delta_{\mathrm{C}} 118.9\right), \mathrm{C}-8 \mathrm{a}\left(\delta_{\mathrm{C}} 139.8\right)$. A quinolone moiety was identified based on the interpretation of COSY and HMBC spectroscopic data. The COSY correlation of $\mathrm{H}-2\left(\delta_{\mathrm{H}} 8.01\right)$ with $\mathrm{H}-3\left(\delta_{\mathrm{H}} 6.37\right)$ and long-range HMBC correlations from $\mathrm{H}-2$ to C-4 $\left(\delta_{\mathrm{C}}\right.$ 179.8) indicated the presence of an $\alpha, \beta$-unsaturated carbonyl group. Furthermore, three-bond HMBC correlations from $\mathrm{H}-2$ to $\mathrm{C}-8 \mathrm{a}$ and from $\mathrm{H}-3$ to $\mathrm{C}-4 \mathrm{a}$, along with the carbon chemical shifts of C-2 $\left(\delta_{\mathrm{C}} 142.2\right)$ and C-8a $\left(\delta_{\mathrm{C}} 142.2\right)$, and correlations from H-6 to C-4a $\left(\delta_{\mathrm{C}} 125.1\right)$ and C-8 $\left(\delta_{\mathrm{C}} 118.9\right)$, and from $\mathrm{H}-5$ to $\mathrm{C}-4, \mathrm{C}-7\left(\delta_{\mathrm{C}} 142.2\right)$ and C-8a $\left(\delta_{\mathrm{C}} 139.8\right)$ allowed for the construction of the quinolone moiety. The carbon chemical shift at $\delta_{\mathrm{C}} 142.2$ and the isotope ratio (3:1) of two pseudomolecular ion peaks $[\mathrm{M}+\mathrm{H}]^{+}$and $[\mathrm{M}+\mathrm{H}+2]^{+}$ in the LR-ESI-MS spectroscopic data (Figure S19), allowed the attachment of a chlorine atom at C-7. Compound 3 was assigned as 7-chloro-4 $(1 \mathrm{H})$-quinolone (Figure 4$)$. The structural assignment of 3 was completed by comparing the NMR data with the data from the literature [22]. 
Compound 3 has been reported as a synthesized product [22] but this is the first report from a natural source (i.e., a bacterium). Compound 3 was approved as an antitumor drug for the treatment of late mammary cancer and non-small cell lung cancer by the SFDA (State Food and Drug Administration of China) due to its capacity to damage DNA and block DNA synthesis in tumor cells [23]. Furthermore, 3 was found to exhibit weak inhibitory activity on cysteine protease [24].

In addition to 1-3, four known natural products were isolated and identified as acremonidin E (4), pinselin (5), penicitrinone A (6), and penicitrinone $E$ (7) by comparing their NMR and MS spectroscopic data with those of previously reported compounds. Interestingly, the known compounds were originally isolated from fungi and had never been reported to be produced by actinomycetes. Acremonidine E (4), penicitrinon A (6), and penicitrinon E (7) were isolated from Penicillium sp. [25-27], whereas pinselin (5) was previously identified in the endophytic fungus Phomopsis sp. [28], the marine fungus Scopuariopsis sp. [29], and the soil fungus Penicillium sp. [30]. In this study, a largescale regrowth of the strain CNQ-490 allowed us to identify the minor compounds (1-7) produced by this strain as well as to rediscover the major compounds such as lodopyridones A-C, sacchromonopyrones A-C, and saccharoquinoline [7-10]. These data suggest that strain CNQ-490 has very good potential in producing biosynthetically-diverse secondary metabolites.

Compounds 1-7 were tested for their antibacterial activities against three Grampositive bacteria (Bacillus subtilis KCTC1021, Kocuria rhizophila KCTC1915, and Staphylococcus aureus KCTC1927), and three Gram-negative bacteria (Escherichia coli KCTC2441, Salmonella typhimurium KCTC2515, and Klebsiella pneumoniae KCTC2690) (Table 2). In addition, quorum sensing (QS) inhibitory activity was evaluated with compounds 2, and 4-7 against six pathogenic bacteria (Cobetia marina strain JEA023, S. aureus KCTC1927, Micrococcus luteus SCO560, Pseudomonas aeruginosa SNC165, Pseudomonas fluorescens SND204, and Agrobacterium tumefaciens SND195) (Table 3). The QS inhibitory activities of compounds 1 and 3 were not investigated, as these compounds could only be recovered in limited amounts. Compound 7 displayed strong antibacterial activity and weak QS inhibitory effect against $S$. aureus KCTC1927 with the values of $2.0 \mu \mathrm{g} / \mathrm{mL}$ and $64 \mu \mathrm{g} / \mathrm{mL}$, respectively. Compound 2 performed weak inhibitory activities against B. subtilis KCTC1021 and S. aureus KCTC1927, with minimum inhibitory concentration (MIC) values of $32 \mu \mathrm{g} / \mathrm{mL}$ and $64 \mu \mathrm{g} / \mathrm{mL}$, respectively. Furthermore, Compounds 5 and 6 exhibited strong QS blocking activities against $C$. marina JEA023 with the value $0.5 \mu \mathrm{g} / \mathrm{mL}$ and $1.0 \mu \mathrm{g} / \mathrm{mL}$, respectively. Meanwhile, compounds 2, 4, and 6 exhibited QS blocking activities against $M$. luteus SCO560 at a 1-64 $\mu \mathrm{g} / \mathrm{mL}$ range. None of the evaluated compounds exhibited QS inhibitory effects against $P$. aeruginosa SNC165, P. fluorescens SND204, and A. tumefaciens SND195.

Table 2. Minimum inhibitory concentration (MIC) of 1-7 against Gram-positive and Gram-negative bacterial strains.

\begin{tabular}{ccccccc}
\hline & \multicolumn{3}{c}{ MIC $(\mu \mathrm{g} / \mathrm{mL})$} \\
\cline { 2 - 7 } Compound & \multicolumn{3}{c}{ Gram (+) Bacteria } & \multicolumn{4}{c}{ Gram (-) Bacteria } \\
\cline { 2 - 7 } & $\begin{array}{c}\text { B. subtilis } \\
\text { KCTC1021 }\end{array}$ & $\begin{array}{c}\text { K. rhizophila } \\
\text { KCTC1915 }\end{array}$ & $\begin{array}{c}\text { S. aureus } \\
\text { KCTC1927 }\end{array}$ & $\begin{array}{c}\text { E. coli } \\
\text { KCTC2441 }\end{array}$ & $\begin{array}{c}\text { S. typhimurium } \\
\text { KCTC2515 }\end{array}$ & $\begin{array}{c}\text { K. pneumonia } \\
\text { KCTC2690 }\end{array}$ \\
\hline $\mathbf{1}$ & $>128$ & $>128$ & $>128$ & $>128$ & $>128$ & $>128$ \\
$\mathbf{2}$ & 32 & $>128$ & 64 & $>128$ & $>128$ & $>128$ \\
$\mathbf{3}$ & $>128$ & $>128$ & $>128$ & $>128$ & $>128$ & $>128$ \\
$\mathbf{4}$ & $>128$ & $>128$ & $>128$ & $>128$ & $>128$ & $>128$ \\
$\mathbf{5}$ & $>128$ & $>128$ & $>128$ & $>128$ & $>128$ & $>128$ \\
$\mathbf{6}$ & $>128$ & $>128$ & $>128$ & $>128$ & 128 & $>128$ \\
$\mathbf{7}$ & $>128$ & $>128$ & 2 & $>16$ & $>128$ & $>128$ \\
Ampicillin & 1 & 0.5 & 1 & $>128$ & & $>128$ \\
Vancomycin & 0.25 & 1 & &
\end{tabular}


Table 3. Anti-quorum sensing activity of 2, 4-7.

\begin{tabular}{|c|c|c|c|c|c|c|}
\hline \multirow{3}{*}{ Compound } & \multicolumn{6}{|c|}{ Anti-Quorum Sensing $(\mu \mathrm{g} / \mathrm{mL})$} \\
\hline & \multicolumn{6}{|c|}{ Bacteria } \\
\hline & $\begin{array}{l}\text { C. marina } \\
\text { JEA023 }\end{array}$ & $\begin{array}{l}\text { S. aureus } \\
\text { KCTC1927 }\end{array}$ & $\begin{array}{c}\text { M. luteus } \\
\text { SCO560 }\end{array}$ & $\begin{array}{l}\text { P. aeruginosa } \\
\text { SNC165 }\end{array}$ & $\begin{array}{l}\text { P. fluorescens } \\
\text { SND204 }\end{array}$ & $\begin{array}{l}\text { A. tumefaciens } \\
\text { SND195 }\end{array}$ \\
\hline 2 & $>128$ & 32 & 64 & $>128$ & $>128$ & $>128$ \\
\hline 4 & $>128$ & 16 & 32 & $>128$ & $>128$ & $>128$ \\
\hline 5 & 0.5 & 64 & $>128$ & $>128$ & $>128$ & $>128$ \\
\hline 6 & 16 & 8 & 1 & $>128$ & $>128$ & $>128$ \\
\hline 7 & $>128$ & 64 & $>128$ & $>128$ & $>128$ & $>128$ \\
\hline Kanamycin & 2 & 8 & 16 & $>128$ & 16 & 64 \\
\hline Rifampin & 8 & 0.25 & 0.25 & 4 & 4 & 1 \\
\hline
\end{tabular}

\section{Materials and Methods}

\subsection{General Experimental Procedures}

UV spectra were recorded in $\mathrm{MeOH}$ on a Scinco UVS2100 spectrophotometer. IR spectra were collected using a Nicolet iS10 FT-IR spectrometer (Thermo Scientific Inc., Waltham, MA, USA). NMR spectra were obtained using an Agilent NMR spectrometer (Agilent, Santa Clara, CA, USA, at 400 for ${ }^{1} \mathrm{H}$ and at $100 \mathrm{MHz}$ for ${ }^{13} \mathrm{C}$ ) and a Bruker NMR spectrometer (Bruker, Middlesex, MA, USA, at 300 for ${ }^{1} \mathrm{H}$ and and $75 \mathrm{MHz}$ for ${ }^{13} \mathrm{C}$ ) using the signals of the residual solvent as internal references $\left(\delta_{\mathrm{H}} 2.50 \mathrm{ppm}\right.$ and $\delta_{\mathrm{C}} 39.5 \mathrm{ppm}$ for dimethyl sulfoxide- $d_{6}$ (DMSO- $d_{6}$ ) and $\delta_{\mathrm{H}} 4.87$ and $3.31 \mathrm{ppm}$ and $\delta_{\mathrm{C}} 49.1 \mathrm{ppm}$ for deuterated methanol $\left(\mathrm{CD}_{3} \mathrm{OD}\right)$. Low-resolution LC/MS measurements were performed using the Agilent Technologies 1260 quadrupole and Waters Micromass ZQ LC/MS system using a reversed-phase column (Phenomenex Luna C18 (2) $100 \AA .50 \mathrm{~mm} \times 4.6 \mathrm{~mm}$, $5 \mu \mathrm{m})$ at a flow rate of $1.0 \mathrm{~mL} / \mathrm{min}$ at the National Research Facilities and Equipment Center (NanoBioEnergy Materials Center) at Ewha Womans University. Open column chromatography was performed using silica (40-63 $\mu \mathrm{m}$, Merck silica gel 60) eluting with a gradient solvent of dichloromethane $\left(\mathrm{CH}_{2} \mathrm{Cl}_{2}\right)$ and methanol $(\mathrm{MeOH})$. The fractions were purified via semi-preparative HPLC using a Waters 996 Photodiode Array Detected HPLC coupled with a reversed-phase Phenomenex Luna C18 (2) $(100 \AA$ A, $250 \mathrm{~nm} \times 10 \mathrm{~mm}$, $5 \mu \mathrm{m}$ ) column at a $2.0 \mathrm{~mL} / \mathrm{min}$ flow rate. High-resolution mass spectra were recorded on a JMS-700 mass spectrometer (JEOL Ltd., Tokyo, Japan) at Seoul National University.

\subsection{Strain Isolation and Fermentation}

Strain CNQ-490 is an actinomycete that was isolated from a marine sediment sample obtained at a depth of $45 \mathrm{~m}$ from a submarine canyon in La Jolla, CA. Strain CNQ-490 was assigned to the genus Saccharomonospora based on 16S ribosomal DNA gene sequence similarity analyses and BLAST searches (GeneBank accession number EU214929). A total of $80 \mathrm{~L}$ of CNQ-490 was cultured in $20 \times 2.5 \mathrm{~L}$ Ultra-Yield flasks (Thomson Scientific, Oceanside, CA, USA) each containing $1 \mathrm{~L}$ of the medium $(10 \mathrm{~g} / \mathrm{L}$ soluble starch, $2 \mathrm{~g} / \mathrm{L}$ yeast, $4 \mathrm{~g} / \mathrm{L}$ peptone, $10 \mathrm{~g} / \mathrm{L} \mathrm{CaCO}_{3}, 20 \mathrm{~g} / \mathrm{L} \mathrm{KBr}, 8 \mathrm{~g} / \mathrm{L} \mathrm{Fe}_{2}\left(\mathrm{SO}_{4}\right)_{3} \cdot 4 \mathrm{H}_{2} \mathrm{O}$ dissolved in $750 \mathrm{~mL}$ natural seawater and $250 \mathrm{~mL}$ of distilled water) at $27^{\circ} \mathrm{C}$ with constant shaking at $150 \mathrm{rpm}$. After 7 days of cultivation, the broth was extracted with ethyl acetate (EtOAc, $80 \mathrm{~L}$ overall) and the EtOAc-soluble fraction was dried in vacuo to obtain $6.5 \mathrm{~g}$ of organic extract.

\subsection{Purification}

The organic extract of CNQ-490 was fractionated by reversed-phase C-18 flash vacuum chromatography eluting with a step gradient from 0 to $100 \%$ methanol in water, which resulted in 11 fractions. Both fractions 3 and 4 (eluted with $9 \%$ and $10 \% \mathrm{MeOH}$ in water, respectively) were further purified by HPLC (Phenomenex $100 \AA$, $250 \mathrm{~nm} \times 10 \mathrm{~mm}, 5 \mu \mathrm{m}$, $\mathrm{UV}=285 \mathrm{~nm}$ ), with $60 \%$ of acetonitrile in $\mathrm{H}_{2} \mathrm{O}$ at a flow rate of $2.0 \mathrm{~mL} / \mathrm{min}$ to yield 1 $\left(1.2 \mathrm{mg}, \mathrm{t}_{\mathrm{R}} 33.7 \mathrm{~min}\right), 45 \%$ of acetonitrile in $\mathrm{H}_{2} \mathrm{O}$ at a flow rate $2.0 \mathrm{~mL} / \mathrm{min}$ to yield $2(4.1 \mathrm{mg}$, 
$\left.\mathrm{t}_{\mathrm{R}} 27.5 \mathrm{~min}\right), 4\left(40.3 \mathrm{mg}, \mathrm{t}_{\mathrm{R}} 17.0 \mathrm{~min}\right), 5\left(6.0 \mathrm{mg}, \mathrm{t}_{\mathrm{R}} 40.0 \mathrm{~min}\right), 6\left(4.8 \mathrm{mg}, \mathrm{t}_{\mathrm{R}} 18.0 \mathrm{~min}\right)$, and $7\left(6.7 \mathrm{mg}, \mathrm{t}_{\mathrm{R}} 35.5 \mathrm{~min}\right)$, and $25 \%$ of acetonitrile in $\mathrm{H}_{2} \mathrm{O}$ at flow rate $2.0 \mathrm{~mL} / \mathrm{min}$ to yield 3 $\left(1.7 \mathrm{mg}, \mathrm{t}_{\mathrm{R}} 33.6 \mathrm{~min}\right)$.

Saccharobisindole (1): Pale yellow oil, $[\alpha]_{\mathrm{D}}^{25}=+161(c 0.29, \mathrm{MeOH}), \mathrm{UV}(\mathrm{MeOH}) \lambda_{\max }$ ( $\log \varepsilon) 202$ (2.93), 253 (2.64), 271 (2.08) nm; IR (KBr) $v_{\max } 3431,2935,1676,1638,1444,1196$, $994 \mathrm{~cm}^{-1},{ }^{1} \mathrm{H}$ and ${ }^{13} \mathrm{C}$ NMR data: Table 1 and Figures S1-S5; HR-FAB-MS m/z 417.2181 $[\mathrm{M}+\mathrm{H}]^{+}$(calculated for $\mathrm{C}_{26} \mathrm{H}_{29} \mathrm{~N}_{2} \mathrm{O}_{3}, 417.2178$ ).

Neoasterric methyl ester (2): Yellowish oil, UV (MeOH) $\lambda_{\max }(\log \varepsilon) 216$ (2.42), 262 (1.93), 397 (1.65) nm; IR (KBr) $v_{\max } 3320,1660,1616,1439,1314,1201,1077 \mathrm{~cm}^{-1},{ }^{1} \mathrm{H}$ and ${ }^{13} \mathrm{C}$ NMR data: Table 1 and Figures S8-S12; HR-FA-BMS $m / z 348.0849[\mathrm{M}+\mathrm{H}]^{+}$(calculated $^{2}$ for $\left.\mathrm{C}_{17} \mathrm{H}_{16} \mathrm{O}_{8}, 348.0845\right)$.

7-Chloro-4(1H)-quinolone (3): White amorphous powder, $\mathrm{UV}(\mathrm{MeOH}) \lambda_{\max }(\log \varepsilon)$ 218 (2.58), 278 (1.87), 279 (1.77) nm; IR (KBr) $v_{\max } 3326,1729,1457,802 \mathrm{~cm}^{-1},{ }^{1} \mathrm{H}$ and ${ }^{13} \mathrm{C}$ NMR data: Table 1 and Figures S13-S17; HR-FAB-MS m/z $180.0218[\mathrm{M}+\mathrm{H}]^{+}$(calculated for $\left.\mathrm{C}_{9} \mathrm{H}_{6}{ }^{35} \mathrm{ClNO}, 180.0216\right)$.

Acremonidine E (4): ${ }^{1} \mathrm{H}$ NMR: (400 MHz, DMSO- $\left.d_{6}\right) ; \delta_{\mathrm{H}} 11.36$ (s, 2-OH), 11.36 (s, 6-OH), $9.70\left(\mathrm{~s}, 1^{\prime}-\mathrm{OH}\right), 9.18\left(\mathrm{~s}, 4^{\prime}-\mathrm{OH}\right), 6.94\left(\mathrm{~d}, J=8.8 \mathrm{~Hz}, \mathrm{H}-5^{\prime}\right), 6.80\left(\mathrm{~d}, J=8.8 \mathrm{~Hz}, \mathrm{H}-6^{\prime}\right)$, 6.10 (s, H-5), 6.10 (s, H-6), 3.54 (s, H-8'), 2.16 (s, H-7), ${ }^{13} \mathrm{C}\left(100 \mathrm{MHz}, \mathrm{DMSO}-d_{6}\right) ; \delta_{\mathrm{C}} 180.2$ (C-8), 167.9 (C-7'), 161.5 (C-2), 161.5 (C-6), $151.1\left(\mathrm{C}-1^{\prime}\right) .147 .7(\mathrm{C}-4), 145.6\left(\mathrm{C}-4^{\prime}\right), 131.2\left(\mathrm{C}-3^{\prime}\right)$, $122.1\left(\mathrm{C}-5^{\prime}\right), 117.4\left(\mathrm{C}-6^{\prime}\right), 112.3\left(\mathrm{C}-2^{\prime}\right), 108.9(\mathrm{C}-1), 107,4(\mathrm{C}-3), 107.4(\mathrm{C}-5), 51.9\left(\mathrm{C}-8^{\prime}\right), 21.6$ (C-7), LR-ESI-MS m/z $319.1[\mathrm{M}+\mathrm{H}]^{+}$.

Pinselin (5): ${ }^{1} \mathrm{H}$ NMR:(400 MHz, DMSO- $\left.d_{6}\right) ; \delta_{\mathrm{H}} 12.18$ (s, 2-OH), 10.47 (s, $\left.1^{\prime}-\mathrm{OH}\right), 7.45$ $\left(\mathrm{d}, J=9.1 \mathrm{~Hz}, \mathrm{H}-5^{\prime}\right), 7.60\left(\mathrm{~d}, J=9.1 \mathrm{~Hz}, \mathrm{H}-6^{\prime}\right), 6.89$ (s, H-5), 6.65 (s, H-3), 3.84 (s, H-8' $), 2.39$ $(\mathrm{s}, \mathrm{H}-7) ;{ }^{13} \mathrm{C}\left(100 \mathrm{MHz}, \mathrm{DMSO}-d_{6}\right) ; \delta_{\mathrm{C}} 180.2(\mathrm{C}-8), 166.8\left(\mathrm{C}-7^{\prime}\right), 160.4(\mathrm{C}-2), 155.4(\mathrm{C}-6), 150.7$ $\left(\mathrm{C}-1^{\prime}\right), 149.3(\mathrm{C}-4), 148.8\left(\mathrm{C}-4^{\prime}\right), 125.3\left(\mathrm{C}-5^{\prime}\right), 120.1\left(\mathrm{C}-6^{\prime}\right), 117.2\left(\mathrm{C}-3^{\prime}\right), 117.0\left(\mathrm{C}-2^{\prime}\right), 110.7$ (C-3), 107.4 (C-5), 106.0 (C-1), 52.2 (C-8'), 22.0 (C-7), LR-ESI-MS m/z $301.1[\mathrm{M}+\mathrm{H}]^{+}$.

Penicitrinon A (6): ${ }^{1} \mathrm{H}$ NMR: $\left(400 \mathrm{MHz}, \mathrm{CD}_{3} \mathrm{OD}\right) ; \delta_{\mathrm{H}} 8.36\left(\mathrm{~s}, 6^{\prime}-\mathrm{OH}\right), 6.68(\mathrm{~s}, \mathrm{H}-7), 5.38$ $(\mathrm{q}, J=6.8 \mathrm{~Hz}, \mathrm{H}-3), 4.71\left(\mathrm{dq}, J=6.7\right.$ and $\left.4.0 \mathrm{~Hz}, \mathrm{H}-2^{\prime}\right), 3.48(\mathrm{q}, J=6.8 \mathrm{~Hz}, \mathrm{H}-4), 3.36(\mathrm{dq}$, $J=6.7$ and $\left.4.0 \mathrm{~Hz}, \mathrm{H}-3^{\prime}\right), 2.30\left(\mathrm{~s}, 5^{\prime}-\mathrm{CH}_{3}\right), 2.22\left(\mathrm{~s}, 5-\mathrm{CH}_{3}\right), 1.45\left(\mathrm{~d}, J=6.8 \mathrm{~Hz}, 3-\mathrm{CH}_{3}\right), 1.42(\mathrm{~d}$, $\left.J=6.7 \mathrm{~Hz}, 2^{\prime}-\mathrm{CH}_{3}\right), 1.35\left(\mathrm{~d}, J=6.7 \mathrm{~Hz}, 3^{\prime}-\mathrm{CH}_{3}\right), 1.34\left(\mathrm{~d}, J=6.8 \mathrm{~Hz}, 4-\mathrm{CH}_{3}\right),{ }^{13} \mathrm{C}(100 \mathrm{MHz}$, $\left.\mathrm{CD}_{3} \mathrm{OD}\right) ; \delta_{\mathrm{C}} 177.8(\mathrm{C}-6), 167.5(\mathrm{C}-1), 160.3(\mathrm{C}-8), 150.7\left(\mathrm{C}-6^{\prime}\right), 145.6\left(\mathrm{C}-4^{\prime}\right), 138.5\left(\mathrm{C}-7^{\prime} \mathrm{a}\right), 137.4$ (C-5), $128.8(\mathrm{C}-4 \mathrm{a}), 120.1\left(\mathrm{C}-5^{\prime}\right), 105.7\left({\mathrm{C}-7^{\prime}}^{\prime}\right), 102.7(\mathrm{C}-8 \mathrm{a}), 101.6(\mathrm{C}-7), 89.0\left(\mathrm{C}-2^{\prime}\right), 86.3(\mathrm{C}-3)$, $46.3\left(\mathrm{C}-3^{\prime}\right), 45.8(\mathrm{C}-4), 21.2\left(2^{\prime}-\mathrm{CH}_{3}\right), 19.5\left(3^{\prime}-\mathrm{CH}_{3}\right), 18.9\left(3-\mathrm{CH}_{3}\right), 18.8\left(4-\mathrm{CH}_{3}\right), 12.1\left(5^{\prime}-\mathrm{CH}_{3}\right)$, $10.7\left(5-\mathrm{CH}_{3}\right)$, LR-ESI-MS $m / z 381.1[\mathrm{M}+\mathrm{H}]^{+}$.

Penicitrinon E (7): ${ }^{1} \mathrm{H}$ NMR: $\left(400 \mathrm{MHz}, \mathrm{CD}_{3} \mathrm{OD}\right) ; \delta_{\mathrm{H}} 5.17$ (q, $\left.J=6.8 \mathrm{~Hz}, \mathrm{H}-3\right), 4.77$ (dq, $J=6.5$ and $\left.4.2 \mathrm{~Hz}, \mathrm{H}-2^{\prime}\right), 3.29(\mathrm{q}, J=6.8 \mathrm{~Hz}, \mathrm{H}-4), 3.25\left(\mathrm{dq}, J=6.5\right.$ and $\left.4.2 \mathrm{~Hz}, \mathrm{H}-3^{\prime}\right), 2.28$ $\left(\mathrm{s}, 5^{\prime}-\mathrm{CH}_{3}\right), 2.22\left(\mathrm{~s}, 5-\mathrm{CH}_{3}\right), 1.49\left(\mathrm{~d}, J=6.8 \mathrm{~Hz}, 3-\mathrm{CH}_{3}\right), 1.47\left(\mathrm{~d}, J=6.7 \mathrm{~Hz}, 2^{\prime}-\mathrm{CH}_{3}\right), 1.38(\mathrm{~d}$, $\left.J=7.0 \mathrm{~Hz}, 4-\mathrm{CH}_{3}\right), 1.36\left(\mathrm{~d}, J=7.0 \mathrm{~Hz}, 3^{\prime}-\mathrm{CH}_{3}\right)$, LR-ESI-MS m/z $425.1[\mathrm{M}+\mathrm{H}]^{+}$.

\subsection{Minimum Inhibitory Concentration (MIC) against Gram-Positive and Gram-Negative Bacteria}

For the antibacterial susceptibility assays, compounds 1-7 were tested against three Gram-positive bacteria (B. subtilis KCTC1021, K. rhizophila KCTC1915, and S. aureus KCTC1927) and three Gram-negative bacteria (E. coli KCTC2441, S. typhimurium KCTC2515, and K. pneumoniae KCTC2690) following the recommendations of previous studies. The bacterial inoculum was prepared in Muller-Hinton broth at $37^{\circ} \mathrm{C}$ and $225 \mathrm{rpm}$ for $24 \mathrm{~h}$. The stock solution of compounds 1-7 and the positive control were dissolved at a $10 \mathrm{mg} / \mathrm{mL}$ concentration in DMSO and diluted with Muller-Hinton broth to obtain a $0.25-256 \mu \mathrm{g} / \mathrm{mL}$ concentration range. Bacterial inoculum $\left(5 \times 10^{5} \mathrm{CFU} / \mathrm{mL}\right.$ concentration) was then dispensed into each well. The resulting mixtures consisting of varying concentrations of compounds 1-7 with a $1 \times 10^{6} \mathrm{CFU} / \mathrm{mL}$ concentration of bacterial inoculum were transferred to 96 well microtiter plates and incubated at $37^{\circ} \mathrm{C}$ for $24 \mathrm{~h}$. 


\subsection{Detection of Anti-Quorum Sensing Activity}

The 96-well plate method was employed to detect the anti-quorum sensing activity of different compounds against six bacterial strains (C. marina JEA023, M. luteus SCO560, S. aureus KCTC1927, P. aeruginosa SNC165, P. fluorescens SNA239, and A. tumefaciens SND195). S. aureus KCTC1927 and A. tumefaciens SND195 were cultured in tryptic soy broth (TSB), whereas P. aeruginosa SNC165 and P. fluorescens SND204 were cultured in King's broth (KB). C. marina JEA023 and M. luteus SCO560 were cultured in marine broth maintaining a $0.5 \mathrm{McF}$ arland standard turbidity $\left(1.0 \times 10^{8} \mathrm{CFU} / \mathrm{mL}\right)$. Dimethyl sulfoxide $(100 \%$ DMSO) was used as a negative control, and kanamycin and rifampin $(10 \mathrm{mg} / \mathrm{mL}$ each) were used as a positive control. Next, $50 \mu \mathrm{L}$ of inoculum was inoculated into each well and $10 \mathrm{mg} / \mathrm{mL}$ of compound 2 and 4-7 dissolved in DMSO was diluted with marine broth media to produce concentrations ranging from 0.25 to $256 \mu \mathrm{g} / \mathrm{mL}$. The mixtures of compounds and broth were dispensed into each inoculated well. The 96-well plates were then incubated for $16-18 \mathrm{~h}$ at $37^{\circ} \mathrm{C}$ depending on the bacterial strains.

\subsection{Conformational Analysis and ECD Spectrum Calculations}

A conformational analysis of saccharobisindole (1) was carried out by MacroModel with the Merck molecular force field (gas phase), a $10 \mathrm{~kJ} / \mathrm{mol}$ upper energy limit, and a $0.001 \mathrm{~kJ}(\mathrm{~mol} \AA)^{-1}$ convergence threshold on the rms gradient to minimize computational complexity and expense. The possible enantiomers of $\mathbf{1}$ were selected based on NOESY NMR data and the energy-minimized enantiomer structures were generated by Avogadro 1.2.0. Energy minimization of the two structures was performed by Turbomole $X$ 4.3.2. The calculated ECD spectra corresponding to two enantiomer models were calculated using DFT at the functional B3LYP/DFT level and the def-SV $(\mathrm{P})$ basis set. The ECD spectra were simulated by overlapping each transition, where $\sigma$ is the width of the band at $1 / e$ height. $\Delta E i$ is the excitation energies and $R i$ is rotatory strengths for transition $i$. In this calculation, the $\sigma$ value was at $0.10 \mathrm{eV}$. The observed ECD spectrum of compound 1 showed positive cotton effect around $291 \mathrm{~nm}$. Comparing the calculated spectra of the two enantiomers with the measured ECD spectrum, the absolute configurations of compound 1 were deduced as $R, S$.

$$
\Delta \epsilon(E)=\frac{1}{2.297 \times 10^{-39}} \frac{1}{\sqrt{2 \pi \sigma}} \sum_{i}^{A} \Delta E_{i} R_{i} e^{\left[-\left(E-\Delta E_{i}\right)^{2} /(2 \sigma)^{2}\right]}
$$

\section{Conclusions}

The identification of the chemical components produced by strain CNQ-490 has led to the discovery of the new compounds saccharobisindole (1), neoasterric methyl ester (2), and 7-chloro-4(1H)-quinolone (3), in addition to four known compounds. Compound $\mathbf{1}$ is an isatin derivative and 2 contains two substituted benzene methyl esters with an ether linkage. Compound 3 possesses a chloroquinolone moiety and our study was the first to isolate this compound from a natural source. Additionally, our study was the first to isolate compounds 4-7, reported as fungal metabolites, from a bacterial strain. Compound 2 exhibited antibacterial activity against B. subtilis KCTC 1021 and S. aureus KCTC 1927, as well as a weak QS inhibitory activity against S. aureus KCTC 1927.

Supplementary Materials: The following are available online at https: / www.mdpi.com/article/ 10.3390/md20010035/s1, Figures S1-S8: 1D and 2D NMR, high resolution mass data, \& calculated optical rotation of compound 1; Figures S9-S13: 1D and 2D NMR data of compound 2; Figures S14-S19: 1D and 2D NMR, and LR-ESI-MS spectroscopic data of compound 3; Figures S20-S26: ${ }^{1} \mathrm{H}$ and ${ }^{13} \mathrm{C}$ NMR of compounds 4-7. 
Author Contributions: S.K. and T.C.L. did large culture, isolated the compounds, elucidated the chemical structure and contributed to manuscript writing. S.-A.H. contributed to manuscript writing. P.F.H. contributed to writing the manuscript and did the bioactivity test. A.H. did fractionation and contributed to LC analysis of crude extract. S.H., Y.E.D. and D.-C.O. did the calculation of the optical rotation, ECD and contributed to writing the manuscript. H.K. and S.-S.C. did the bioassay. J.L. and S.-J.N. were the project leader for guiding the experiments and for writing the manuscript. W.F. provided the microbial strain and contributed to writing the manuscript. and S.-J.N. contributed to supervision and conceptualization. All authors reviewed the manuscript. All authors have read and agreed to the published version of the manuscript.

Funding: This research was supported by National Research Foundation of Korea Grants funded by the Korean Government (Ministry of Science and ICT; 2021R1A4A2001251 to S.-J.N.), in part by the Korea Polar Research Institute Grant PM21030 (15250103 to S.-S.C.) and funded by the Ministry of Oceans and Fisheries, Korea grant numbers and in part by the U.S. NIH National Cancer Institute under grant R37 CA044848 to W.F.

Data Availability Statement: The data presented in this study are available on request from the corresponding author.

Conflicts of Interest: The authors declare no conflict of interest.

\section{References}

1. Ding, T.; Yang, L.-J.; Zhang, W.-D.; Shen, Y.-H. The secondary metabolites of rare actinomycetes: Chemistry and bioactivity. RSC Adv. 2019, 9, 21964-21988. [CrossRef]

2. Jose, P.A.; Maharshi, A.; Jha, B. Actinobacteria in natural products research: Progress and prospects. Microbiol. Res. 2021, 246, 12678-12691. [CrossRef]

3. Liu, Z.; Li, Y.; Zheng, L.-Q.; Huang, Y.-J.; Li, W.-J. Saccharomonospora marina sp. nov., isolated from an ocean sediment of the East China Sea. Int. J. Syst. Evol. Microbiol. 2010, 60, 1854-1857. [CrossRef]

4. Veyisoglu, A.; Sazak, A.; Cetin, D.; Guven, K.; Sahin, N. Saccharomonospora amisosensis sp. nov., isolated from deep marine sediment. Int. J. Syst. Evol. Microbiol. 2013, 63, 82-86. [CrossRef] [PubMed]

5. Tamura, A.; Takeda, I. Antibiotic AB-65, a new antibiotic from Saccharomonospora viride. J. Antibiot. 1975, 28, 395-397. [CrossRef]

6. Singh, B.; Parshad, R.; Khajuria, R.K.; Guru, S.K.; Pathania, A.S.; Sharma, R.; Chib, R.; Aravinda, S.; Gupta, V.K.; Khan, I.A. Saccharonol B, a new cytotoxic methylated isocoumarin from Saccharomonospora azurea. Tetrahedron Lett. 2013, 54, $6695-6699$. [CrossRef]

7. Maloney, K.N.; MacMillan, J.B.; Kauffman, C.A.; Jensen, P.R.; DiPasquale, A.G.; Rheingold, A.L.; Fenical, W. Lodopyridone, a structurally unprecedented alkaloid from a marine Actinomycete. Org. Lett. 2009, 11, 5422-5424. [CrossRef] [PubMed]

8. Le, T.C.; Yim, C.-Y.; Park, S.; Katila, N.; Yang, I.; Song, M.C.; Yoon, Y.J.; Choi, D.-Y.; Choi, H.; Nam, S.-J. Lodopyridones B and C from a marine sediment-derived bacterium Saccharomonospora sp. Bioorg. Med. Chem. Lett. 2017, 27, 3123-3126. [CrossRef]

9. Yim, C.-Y.; Le, T.C.; Lee, T.G.; Yang, I.; Choi, H.; Lee, J.; Kang, K.-Y.; Lee, J.S.; Lim, K.M.; Yee, S.T. Saccharomonopyrones A-C, new $\alpha$-pyrones from a marine sediment-derived bacterium Saccharomonospora sp. CNQ-490. Mar. Drugs 2017, 15, 239. [CrossRef]

10. Le, T.C.; Lee, E.J.; Lee, J.; Hong, A.; Yim, C.-Y.; Yang, I.; Choi, H.; Chin, J.; Cho, S.J.; Ko, J. Saccharoquinoline, a cytotoxic alkaloidal meroterpenoid from marine-derived bacterium Saccharomonospora sp. Mar. Drugs 2019, 17, 98. [CrossRef] [PubMed]

11. Yamanaka, K.; Reynolds, K.A.; Kersten, R.D.; Ryan, K.S.; Gonzalez, D.J.; Nizet, V.; Dorrestein, P.C.; Moore, B.S. Direct cloning and refactoring of a silent lipopeptide biosynthetic gene cluster yields the antibiotic taromycin A. Proc. Natl. Acad. Sci. USA 2014, 111, 1957-1962. [CrossRef]

12. Reynolds, K.A.; Luhavaya, H.; Li, J.; Dahesh, S.; Nizet, V.; Yamanaka, K.; Moore, B.S. Isolation and structure elucidation of lipopeptide antibiotic taromycin B from the activated taromycin biosynthetic gene cluster. J. Antibiot. 2018, 71, 333-338. [CrossRef]

13. Wu, P.L.; Hsu, Y.L.; Jao, C.W. Indole alkaloids from Cephalanceropsis gracilis. J. Nat. Prod. 2006, 6, 1467-1470. [CrossRef]

14. Wang, Y.; Tang, X.; Shao, Z.; Ren, J.; Liu, D.; Proksch, P.; Lin, W. Indole-based alkaloids from deep-sea bacterium Shewanella piezotolerans with antitumor activities. J. Antibiot. 2014, 67, 395-399. [CrossRef]

15. Hargreaves, J.; Park, J.-O.; Ghisalberti, E.L.; Sivasithamparam, K.; Skelton, B.W.; White, A.H. New chlorinated diphenyl ethers from an Aspergillus species. J. Nat. Prod. 2002, 65, 7-10. [CrossRef]

16. Natori, S.; Nishikawa, H. Structures of osoic Acids and related compounds, metabolites of Oospora sulphurea-ochracea v. BEYMA. Chem. Pharm. Bull. 1962, 10, 117-124. [CrossRef]

17. Chomcheon, P.; Wiyakrutta, S.; Sriubolmas, N.; Ngamrojanavanich, N.; Mahicol, C.; Ruchiraswat, S.; Kittakoop, P. Metabolites from the endophytic mitosporic Dothideomycete sp. LRUB20. Phytochemistry 2009, 70, 121-127. [CrossRef]

18. Fang, M.J.; Fang, H.; Li, W.J.; Huang, D.M.; Wu, Z.; Zhao, Y.F. A new diphenyl ether from Phoma sp. strain, SHZK-2. J. Nat. Prod. 2012, 26, 1224-1228. [CrossRef] [PubMed]

19. Wen, S.; Fan, W.; Guo, H.; Huang, C.; Yan, Z.; Long, Y. Two new secondary metabolites from the mangrove endophytic fungus Pleosporales sp. SK7. J. Nat. Prod. 2020, 34, 2919-2925. [CrossRef] [PubMed] 
20. Talonsti, F.M.; Lamshöft, M.; Douanla-Meli, C.; Kouan, S.F.; Spiteller, M. Antiplasmodial and cytotoxic dibenzofurans from Preussia sp. harboured in Enantia chlorantha Oliv. Fitoterapia 2014, 93, 223-238.

21. Li, Y.; Sun, B.; Liu, S.; Jiang, L.; Liu, X.; Zhang, H.; Che, Y. Bioactive asterric acid derivatives from the Antarctic ascomycete fungus Geomyces sp. J. Nat. Prod. 2008, 71, 1643-1646. [CrossRef] [PubMed]

22. Giorgi-Renault, S.; Renault, J.; Bukovec, Z. Phase Transfer Catalysis: A Convenient Synthesis of O,O-Diethyl O-(4-Quinolinyl) Phosphorothioates. Synthesis 1984, 9, 491-493. [CrossRef]

23. Zhou, P.; Huang, L.; Zhou, J.; Jiang, B.; Zhao, Y.; Deng, X.; Zhao, Q.; Li, F. Discovery of novel 4(1H)-quinolone derivatives as potential antiproliferative and apoptosis inducing agents. Bioorg. Med. Chem. Lett. 2017, 27, 4185-4189. [CrossRef] [PubMed]

24. Andrade, M.M.; Martins, L.C.; Marques, G.V.; Silva, C.A.; Faria, G.; Caldas, S.; Santos, J.S.; Leclercq, S.Y.; Maltarollo, V.; Ferreira, R.S.; et al. Synthesis of quinoline derivatives as potential cysteine protease inhibitors. Future Med. Chem. 2020, 12, 571-581. [CrossRef] [PubMed]

25. Kim, K.; Jeong, H.-I.; Yang, I.; Nam, S.-J.; Lim, K.-M. Acremonidine E produced by Penicillium sp. SNF123, a fungal endophyte of Panax ginseng, has antimelanogenic activities. J. Ginseng. Res. 2021, 45, 98-107. [CrossRef] [PubMed]

26. Wakana, D.; Hosoe, T.; Itabashi, T.; Okada, K.; Takaki, G.M.C.; Yaguchi, T.; Fukushima, K.; Kawai, K. New citrinin derivatives isolated from Penicillium citrinum. J. Nat. Med. 2006, 60, 279-284. [CrossRef]

27. Wang, M.L.; Lu, C.H.; Xu, Q.Y.; Song, S.Y.; Hu, Z.Y.; Zheng, Z.H. Four new citrinin derivatives from a marine-derived Penicillium sp. fungal strain. Molecules 2013, 18, 5723. [CrossRef]

28. Yang, H.Y.; Gao, Y.H.; Niu, D.-Y.; Yang, L.-Y.; Gao, X.-M.; Du, G.; Hu, Q.-F. Xanthone derivatives from the fermentation products of an endophytic fungus Phomopsis sp. Fitoterapia 2013, 91, 189-193. [CrossRef]

29. Elnaggar, M.S.; Ebada, S.S.; Ashour, M.L.; Ebrahim, W.; Müller, W.E.G.; Mándi, A.; Kurtán, T.; Singab, A.; Lin, W.; Liu, Z.; et al. Xanthones and sesquiterpene derivatives from a marine-derived fungus Scopulariopsis sp. Tetrahedron Lett. 2016, 72, 2411-2419. [CrossRef]

30. Trisuwan, K.; Rukachaisirikul, V.; Borwornwiriyapan, K.; Phongapaichit, S.; Sakayaroj, J. Benzopyranone, benzophenone, and xanthone derivatives from the soil fungus Penicillium citrinum PSU-RSPG95. Tetrahedron Lett. 2014, 55, 1336-1338. [CrossRef] 